DOI: 10.19195/2300-7729.35.3

JULITA NIEDŹWIECKA-AMBROZIAK

Instytut Informacji Naukowej i Bibliologii

Uniwersytetu Mikołaja Kopernika w Toruniu

\title{
Wpływ wykorzystania dotacji ministerialnych i funduszy unijnych na kształtowanie się zbiorów w bibliotece uczelni niepublicznej (na przykładzie Biblioteki Wyższej Szkoły Bankowej w Toruniu)
}

\section{Prawne podstawy działalności uczelni niepaństwowych w Polsce}

Od roku 1991 zaczęły powstawać uczelnie niepaństwowe, tworzone na podstawie ustawy z dnia 12 września 1990 r. Zasadnicze regulacje stanowiły, iż:

Uczelnię niepaństwową może założyć osoba fizyczna lub osoba prawna, zwana dalej „założycielem", na podstawie zezwolenia udzielonego przez Ministra Edukacji Narodowej, po zasięgnięciu opinii Rady Głównej Szkolnictwa Wyższego.

Do uprawnień założyciela zgodnie z ustawą z 1991 r. należało m.in.: nadawanie statutu uczelni, powoływanie rektora, określenie sposobu likwidacji uczelni w statucie, który podlegał zatwierdzeniu przez ministra edukacji narodowej ${ }^{1}$.

Zmiany nastąpiły 26 czerwca 1997 r., kiedy to Sejm przyjął ustawę o wyższych szkołach zawodowych. Kolejna znowelizowana ustawa o szkolnictwie wyższym została przyjęta 20 lipca 2001 r., otwierając drugie dziesięciolecie funkcjonowania i rozwoju niepaństwowego szkolnictwa wyższego w Polsce. Najważniejsze zmiany w zakresie funkcjonowania szkół wyższych dotyczyły utworzenia Państwowej Komisji Akredytacyjnej, zmiany funkcji Rady Głównej Szkolnictwa Wyższego, zniesienia Komisji Akredytacyjnej Wyższego Szkolnictwa Zawodowego. Co waż-

${ }^{1}$ T. Matynia, Podstawy prawne tworzenia i funkcjonowania niepublicznych szkót wyższych w świetle ustawodawstwa polskiego w latach 1920-2013, „Homines Hominibus” 2012, nr 8, s. 92-93. 
ne, ustawa dawała uczelniom zawodowym możliwości ubiegania się o prowadzenie studiów magisterskich i organizacji jednostek zamiejscowych ${ }^{2}$.

Obecnie Konstytucja RP zapewnia szkołom wyższym autonomię, a zasady ich działania określa ustawa Prawo o szkolnictwie wyższym z 27 lipca 2005 r. wraz z nowelizacją z 2014 r., regulując zasady funkcjonowania szkół wyższych publicznych i niepublicznych. Bieżąca działalność uczelni niepaństwowych regulowana jest przepisami ustawy o szkolnictwie wyższym w sposób identyczny jak w uczelniach państwowych, z wyjątkiem nielicznych przypadków, gdy ustawa przewiduje inne regulacje dla szkół niepaństwowych lub zawiera przepisy dopuszczające przyjęcie odmiennych zasad ich funkcjonowania, co dotyczy głównie organizacji uczelni (np. tryb powoływania organów uczelni, ich kompetencji i wzajemnych relacji $)^{3}$.

Przez uczelnię niepubliczną rozumie się w tej ustawie „uczelnię utworzoną przez osobę fizyczną albo osobę prawną niebędącą państwową ani samorządową osobą prawną. Osoba fizyczna lub prawna, która założyła uczelnię, określana jest jako założyciel uczelni niepublicznej”. Warto dodać, iż uczelnie w świetle omawianej ustawy zostały podzielone na zawodowe i akademickie. Do uczelni zawodowych zostały zaliczone uczelnie prowadzące studia licencjackie lub inżynierskie oraz studia magisterskie nieposiadające uprawnień do nadawania stopnia naukowego doktora. Jest to istotna zmiana w stosunku do poprzednich przepisów, według których do uczelni zawodowych zaliczały się te uczelnie, które kształciły studentów wyłącznie na poziomie studiów licencjackich lub inżynierskich ${ }^{4}$.

\section{Szkolnictwo niepubliczne w polskim systemie edukacji}

Aktualny wykaz uczelni niepublicznych znajduje się w Rejestrze uczelni niepublicznych i związków uczelni niepublicznych prowadzonym w systemie POL-on. Zarejestrowanych zostało dotychczas 397 uczelni niepaństwowych. Faktycznie funkcjonuje 270 uczelni. Najmłodsza z nich to Collegium Medicum Wyższa Szkoła Służb Medycznych z siedzibą w Warszawie (poprzednio: Collegium Wyższa Szkoła Służb Medycznych z siedzibą w Warszawie), wpisana do rejestru w marcu 2015 r., natomiast najstarszą działającą uczelnią niepubliczną jest Prywatna Wyższa Szkoła Nauk Społecznych, Komputerowych i Medycznych z siedzibą w Warszawie (poprzednio: Prywatna Wyższa Szkoła Businessu, Administracji i Technik Komputerowych w Warszawie), założona w sierpniu 1991 r.

\footnotetext{
2 Ibidem, s. 94.

${ }^{3}$ Ministerstwo Nauki i Szkolnictwa Wyższego. Zadania Ministerstwa w dziedzinie szkolnictwa wyższego, http://www.nauka.gov.pl/szkolnictwo-wyzsze/ [dostęp: 10.02.2017].

4 T. Matynia, op. cit., s. 94.
} 
Funkcjonuje 39 uczelni mających status uczelni w likwidacji. Dotychczas z rejestru wykreślono 62 uczelnie niepaństwowe. W roku akademickim 2014/2015 uczelnie niepubliczne kształciły 359178 studentów, zatrudniając 13074 nauczycieli akademickich i przyznając dyplomy 122650 absolwentom $^{5}$.

Stwierdzić należy, iż liczba uczelni niepaństwowych wzrastała bardzo szybko do roku akademickiego 2010/2011. W tym okresie było ich 328. Od tamtego czasu nieznacznie, lecz stopniowo maleje. Trudno jednoznacznie ocenić podane liczby — z pewnością pozytywnie należy odnieść się do wzrastającej oferty edukacyjnej w latach wyżu demograficznego, gdyż wobec braku bazy materialnej szkół państwowych była to szansa dla młodzieży, zwłaszcza gdy uczelnie niepubliczne powstawały w mniejszych, oddalonych od miast ośrodkach akademickich.

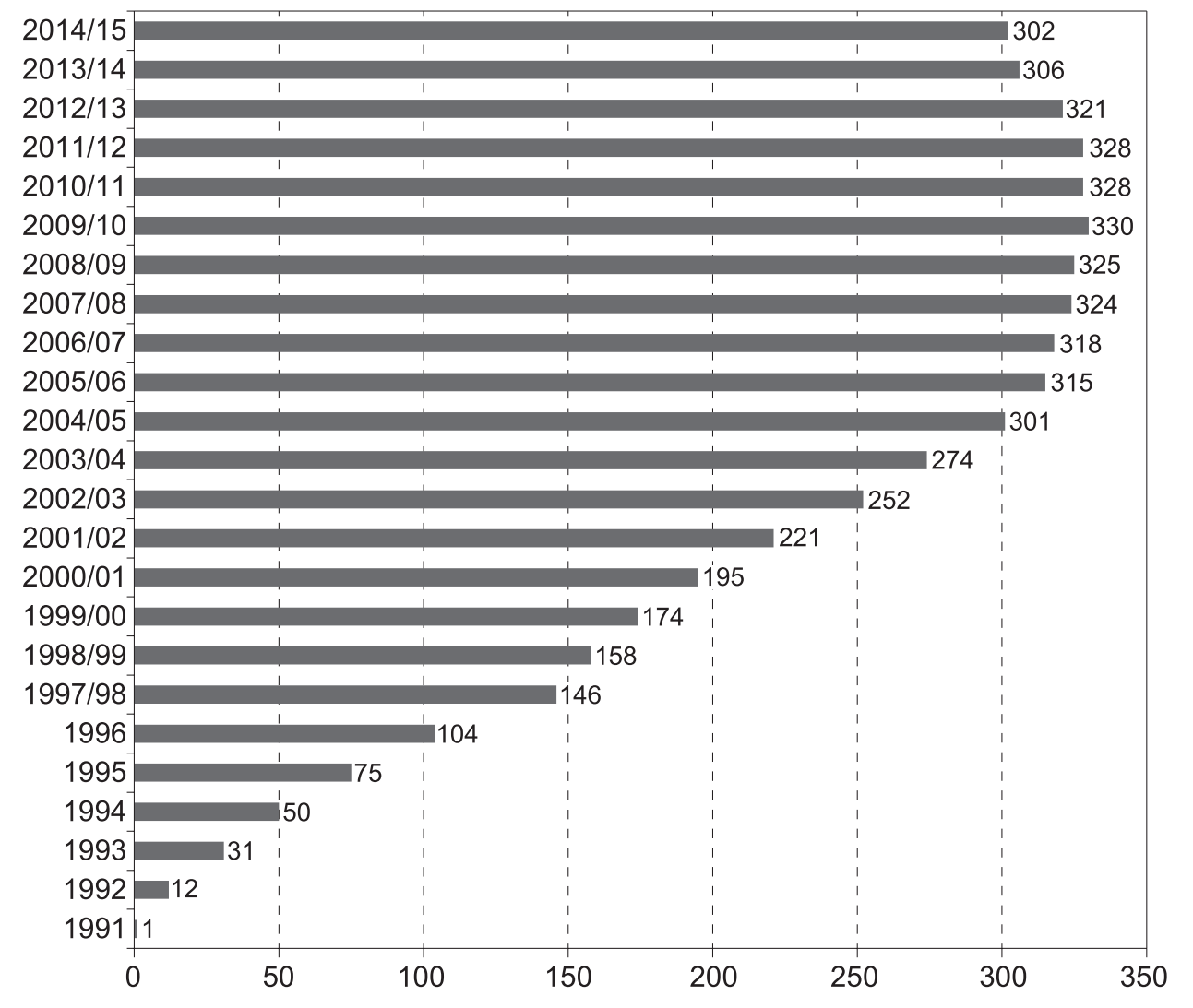

Rys. 1. Liczba uczelni niepaństwowych w poszczególnych latach

Źródło: opracowanie własne na podstawie danych Głównego Urzędu Statystycznego oraz Szkoty wyższe i ich finanse w $2014 \mathrm{r}$.

${ }^{5}$ Uczelnie niepubliczne i związki uczelni niepublicznych. POL-on, https://polon.nauka.gov. pl/opi/aa/rejestry/run?execution=e3s1 [dostęp: 20.06.2016]. 


\section{Systemy biblioteczno-informacyjne uczelni niepaństwowych (przykład bibliotek holdingu TEB Akademia)}

Biblioteki szkół wyższych niepaństwowych powstały, tak jak ich uczelnie macierzyste, stosunkowo niedawno. Jak zauważa Bogumiła Urban w artykule Finanse bibliotek niepaństwowych szkót wyższych, księgozbiory tworzono tu od symbolicznego zakupu pierwszej książki. Proces powstawania tych bibliotek uwarunkował ich cechy, ponieważ księgozbiory gromadzone przez znacznie krótszy czas są dużo mniejsze niż w uczelniach państwowych, są też jednak bardziej aktualne i na bieżąco uzupełniane. Inną cechą charakterystyczną bibliotek uczelni niepaństwowych są zespoły bibliotekarzy: nieliczne, lecz z wysokim poziomem obciążenia obowiązkami. Zwykle znacznie mniejsza grupa bibliotekarzy, w porównaniu z uczelniami państwowymi, obsługuje społeczność akademicką o podobnej wielkości. Przy czym zespoły bibliotekarskie są tu bardzo zintegrowane, elastyczne i utożsamiające się z placówką, którą najczęściej tworzyły od podstaw ${ }^{6}$.

Towarzystwo Edukacji Bankowej SA (dalej TEB) ze względu na swoją strukturę, zakres działalności oraz charakter jest największym konsorcjum edukacyjnym w Europie Wschodniej. To właśnie TEB powołało do życia Centrum Rozwoju Szkół Wyższych TEB Akademia i uczyniło z niego założyciela Wyższych Szkół Bankowych w Gdańsku, Poznaniu, Toruniu i we Wrocławiu, wraz z ich wydziałami zamiejscowymi w Gdyni, Chorzowie, Szczecinie, Bydgoszczy i Opolu. Mechanizm ich powstania obrazuje rys. 2 .

Przy wszystkich szkołach wyższych powstały biblioteki, których jednym z głównych zadań jest tworzenie bogatej bazy materiałów dydaktycznych, będących podstawą efektywnego procesu nauczania. Profil gromadzenia zbiorów jest dostosowany do podstawowych treści dydaktycznych realizowanych przez uczelnię. Wszystkie biblioteki szkół wyższych bankowych były tworzone od podstaw, zwykle na bazie księgozbioru pochodzącego od założyciela uczelni lub jak np. w przypadku biblioteki wydziałowej WSB w Bydgoszczy z księgozbioru przekazanego w depozycie przez ówczesną Bibliotekę Główną w Toruniu ${ }^{7}$ Podstawowym źródłem pozyskiwania zbiorów są zakupy własne, wymiana oraz dary.

${ }^{6}$ B. Urban, Finanse bibliotek niepaństwowych szkót wyższych — zarys tematyki, „Biuletyn EBIB” 2009, nr 8 (108), http://www.ebib.pl/2009/108/a.php?urban [dostęp: 20.06.2016].

${ }^{7}$ Do roku akademickiego 2013/2014 Biblioteka WSB w Toruniu pełniła funkcję Biblioteki Głównej. Obecnie obie biblioteki (bydgoska i toruńska) mają status równorzędnych, mimo to dyrektor Biblioteki WSB w Toruniu zawiaduje systemem informacyjno-bibliotecznym, na mocy dokumentu: Zakres funkcjonowania i struktura organizacyjna bibliotek Systemu biblioteczno-informacyjnego Wyższej Szkoły Bankowej w Toruniu. 


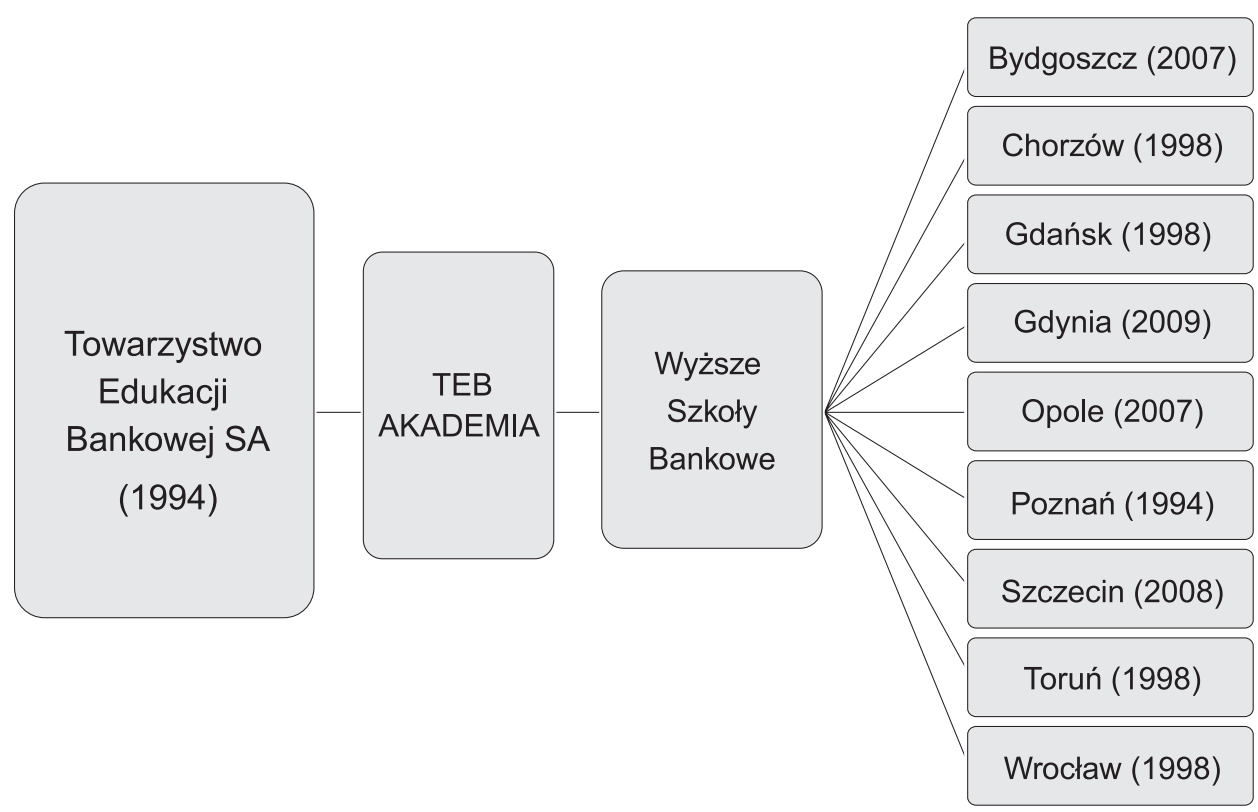

Rys. 2. Założyciele i daty powstania Wyższych Szkół Bankowych Źródło: opracowanie własne.

W obrębie bibliotek holdingu zostały utworzone 4 systemy informacyjno-biblioteczne, którymi zawiadują dyrektorzy bibliotek szkół założycielskich.

Dyrektorom bibliotek szkół wyższych bankowych w Gdańsku, Poznaniu, Wrocławiu i Toruniu przekazano zadania polegające na nadzorze merytorycznym i kontroli nad całym systemem biblioteczno-informacyjnym uczelni, a mianowicie koordynowaniu działalności systemu biblioteczno-informacyjnego uczelni oraz systemu elektronicznej informacji dla studentów; opracowywaniu i wdrażaniu dokumentacji jednolicie obowiązującej i regulującej pracę bibliotek oraz dbaniu o właściwy kierunek rozwoju bibliotek zgodny z ich naukowym charakterem.

W większości przypadków system biblioteczno-informacyjny uczelni podlega rektorowi, tylko we wrocławskiej bibliotece Prorektorowi ds. Badań Naukowych i Współpracy z Gospodarką. We wszystkich bibliotekach organem doradczym i opiniodawczym rektora jest Rada Biblioteczna, której sposób działania precyzują Regulaminy Rady Bibliotecznej poszczególnych systemów informacyjno-bibliotecznych ${ }^{8}$.

\footnotetext{
8 Ibidem.
} 


\section{System}

informacyjno-biblioteczny

Wyższej Szkoły Bankowej

we Wrocławiu
- Biblioteka Wyższej Szkoły Bankowej we Wrocławiu Biblioteka Główna

- Biblioteka Wydziału Ekonomicznego w Opolu Wyższej Szkoły Bankowej we Wrocławiu - Biblioteka Wydziałowa
System

informacyjno-biblioteczny

Wyższej Szkoły Bankowej

w Gdańsku
- Biblioteka Wyższej Szkoły Bankowej w Gdańsku

- Biblioteka Wydziału Ekonomii i Zarządzania w Gdyni

\section{System}

informacyjno-biblioteczny

Wyższej Szkoły Bankowej

w Poznaniu
- Biblioteki wydziałowe:

Biblioteka Wyższej Szkoły Bankowej w Poznaniu, Biblioteka Wyższej Szkoły Bankowej w Chorzowie i Biblioteka Wyższej Szkoły Bankowej w Szczecinie

- Pełnomocnik Rektora ds. systemu biblioteczno-informacyjnego (dyrektor Biblioteki WSB w Poznaniu)

\section{System}

informacyjno-biblioteczny

Wyższej Szkoły Bankowej

w Toruniu
- Biblioteka Wydziału Finansów i Zarządzania w Toruniu (dyrektor pełni nadzór merytoryczny i kontrolę nad systemem biblioteczno-informacyjnym Uczelni)

- Biblioteka Wydziału Finansów i Zarządzania w Bydgoszczy

Rys.3. Składowe systemów informacyjno-bibliotecznych bibliotek WSB ${ }^{9}$

Źródło: opracowanie własne na podstawie regulaminów bibliotek Wyższych Szkół Bankowych.

${ }^{9}$ Regulamin Systemu Biblioteczno-Informacyjnego Wyższej Szkoły Bankowej w Toruniu, http://www.wsb.pl/torun/sites/wsb.pl.torun/files/biblioteka/regulamin_2015.pdf7 [dostęp: 20.06.2016]; Regulamin Systemu Biblioteczno-Informacyjnego Wyższej Szkoły Bankowej w Gdańsku, http://www.wsb.pl/gdansk/sites/wsb.pl.gdansk/files/default_images/biblioteka/regulamin_biblioteki_2013.pdf [dostęp: 20.06.2016]; Regulamin Systemu Biblioteczno-Informacyjnego Wyższej Szkoły Bankowej we Wrocławiu, http://www.wsb.pl/wroclaw/sites/wsb.pl.wroclaw/files/reg_biblio_ wsb-ww_2013.pdf [dostęp: 20.06.2016]; Regulamin Systemu Biblioteczno-Informacyjnego Wyższej Szkoły Bankowej w Poznaniu, http:/www.wsb.pl/poznan/sites/wsb.pl.poznan/files/regulamin_systemu_bib_inf.pdf [dostęp: 20.06.2016]. 


\section{Polityka gromadzenia w bibliotekach wyższych szkół bankowych}

Jednym z elementów kształtujących politykę gromadzenia zbiorów są potrzeby czytelników, a tworzenie optymalnej kolekcji zbiorów biblioteki wyższej uczelni ekonomicznej jest procesem wielowymiarowym. Ogromna liczba wydawnictw drukowanych i elektronicznych, będących konsekwencją rozwoju nauki, oraz nowe technologie dostępu sprawiają, że wybór staje się coraz trudniejszy. Biblioteka wyższej uczelni, z racji powierzonych jej zadań, musi wziąć na siebie rozeznanie rynku wydawniczego, dokonanie jego wstępnej analizy i selekcji, oszacowanie jakości i kosztów nowego produktu, a następnie określenie potrzeb użytkowników i możliwości biblioteki (finanse, sprzęt). Aby procesy te przebiegały sprawnie, za finanse poszczególnych bibliotek odpowiadają ich dyrektorzy bądź kierownicy. Do ich kompetencji należy planowanie budżetowe oraz przestrzeganie utrzymania poziomu kosztów. Biblioteki niepaństwowych szkół wyższych finansowane są głównie z budżetu ogólnego uczelni macierzystej. Do powstania budżetu konieczne jest przygotowanie planu finansowego, będącego głównym instrumentem zarządzania daną instytucją na poziomie operacyjnym. Plan budżetowy (finansowy) to dokument, który obejmuje w formie ilościowej i rzeczowej spodziewane koszty danej jednostki oraz przychody m.in. z naliczonych opłat za nieterminowy zwrot książek (plan działania ujęty w formę finansową) $)^{10}$.

Dynamicznie rozwijającym się źródłem pozyskiwania zbiorów w bibliotekach holdingu TEB są granty i fundusze unijne, zwłaszcza te przeznaczone na podnoszenie kwalifikacji (np. z Europejskiego Funduszu Społecznego). Uczelnie niepaństwowe wygrywają konkursy w programach unijnych z korzyścią dla studentów, których opłaty są znacząco obniżane, i z korzyścią dla samej uczelni, która może poszerzyć swą ofertę edukacyjną ${ }^{11}$; część środków unijnych przeznaczana jest również na wzbogacanie księgozbiorów. Tu należy zaznaczyć, iż dotychczas żadna biblioteka nie była bezpośrednim beneficjentem i wykonawcą projektu unijnego.

\section{WSB Toruń - finansowanie zbiorów i realizacja projektów}

W niniejszym opracowaniu analizę gromadzenia zbiorów opartą na finansowaniu zewnętrznym ograniczono do Biblioteki Wyższej Szkoły Bankowej (WSB) w Toruniu. Skoncentrowano się na nowych formach zbiorów, które wzbogaciły zasoby biblioteki dzięki realizacji dotacji ministerialnej oraz skali finansowania księgozbioru z funduszy unijnych w latach 2011-2016.

\footnotetext{
${ }^{10}$ B. Urban, op. cit.

${ }^{11}$ Ibidem.
} 
Biblioteka WSB w Toruniu powstała w 1998 r.; obecnie jej księgozbiór (książki, zbiory audiowizualne, materiały informacyjne) liczy ok. 42 tys. egzemplarzy i jest na bieżąco aktualizowany. Prenumerowane są specjalistyczne elektroniczne bazy danych, które zgodnie z profilem kształcenia w uczelni mają być pomocne w poszukiwaniu informacji biznesowych, gospodarczych i politycznych. Z usług biblioteki korzystają studenci i pracownicy WSB, słuchacze studiów podyplomowych, kursów i szkoleń oraz osoby niezwiązane z uczelnią. W swych zasobach biblioteka posiada także wydawnictwa ciągłe (w formie drukowanej i elektronicznej): czasopisma branżowe, zeszyty naukowe, roczniki i opracowania statystyczne oraz mapy i dokumenty kartograficzne. Księgozbiór gromadzony w bibliotece jest ściśle dostosowany do profilu uczelni i potrzeb użytkowników, ma służyć zarówno studentom, jak i pracownikom prowadzącym badania naukowe.

Finansowanie, podobnie jak w innych bibliotekach WSB, pochodzi z budżetu ogólnego uczelni. Zarządza nim dyrektor, sporządzając plan finansowy, a następnie, w ramach zaakceptowanych przez władze szkoły finansach, realizując go.

Zakupy dokonywane przez bibliotekarzy specjalistów obejmują:

- zbiory ciągłe: czasopisma, zeszyty naukowe, roczniki itp. Prenumeruje specjalista ds. wydawnictw ciągłych;

— książki w formie tradycyjnej oraz elektronicznej, zbiory specjalne - CD-ROM-y, dokumenty kartograficzne itp. Zakupów dokonuje specjalista ds. wydawnictw zwartych;

— elektroniczne bazy danych. Za negocjacje z kontrahentami odpowiada specjalista ds. informacji naukowej.

Zakupy są realizowane za merytoryczną i finansową zgodą dyrektora biblioteki. W przypadku dotacji unijnych pracownicy przygotowują do zapytań ofertowych lub przetargów listy zbiorów do zakupów. Muszą one być zgodne z sylabusami poszczególnych przedmiotów wykładanych w ramach kierunków dotowanych ze środków unijnych.

\section{Fundusze unijne - realizacja w bibliotece WSB w Toruniu}

W ramach dofinansowania uczelni z Europejskiego Funduszu Społecznego dla biblioteki w projektach zarezerwowano fundusze przede wszystkim na zakup druków zwartych: literatury specjalistycznej i naukowej. Okres programowania obejmował lata 2007-2015. W niniejszym opracowaniu przeanalizowano następujące projekty unijne (2011-2016):

1. Tytuł projektu: WSB w Toruniu jako Centrum Ksztatcenia Otwartego kadr sektora turystycznego, z Europejskiego Funduszu Społecznego, Program Ope- 
racyjny Kapitał Ludzki, działanie: 4.1. Wzmocnienie i rozwój potencjału dydaktycznego uczelni oraz zwiększenie liczby absolwentów kierunków o kluczowym znaczeniu dla gospodarki opartej na wiedzy, poddziałanie: 4.1.1. Wzmocnienie potencjału dydaktycznego uczelni.

W ramach realizacji projektu biblioteka, oprócz księgozbioru o łącznej wartości 80 tys. zł, wzbogaciła się o nowe formy zbiorów, a mianowicie:

— GPS Oregon 550t - 10 szt.,

- oprogramowanie City Navigator Europe NT,

- płyty NU Mapslifetime,

— kompasy - 20 szt.,

— zestawy minerałów i skamieniałości,

— kolekcję map (250 map topograficznych, 100 przeglądowo-topograficznych).

2. Tytuł projektu: Wyższa Szkoła Bankowa w Toruniu - Centrum Kształcenia Logistycznego, z Europejskiego Funduszu Społecznego, Program Operacyjny Kapitał Ludzki, działanie: 4.3. Wzmocnienie potencjału dydaktycznego uczelni w obszarach kluczowych w kontekście celów Strategii Europa 2020. Sfinansowano zakup księgozbioru o wartości ok. 60 tys. zł.

3. Tytuł projektu: Logistyka w nowoczesnej gospodarce - nowe kierunki studiów podyplomowych w WSB w Toruniu, z Europejskiego Funduszu Społecznego, Program Operacyjny Kapitał Ludzki, działanie: 4.3. Wzmocnienie potencjału dydaktycznego uczelni w obszarach kluczowych w kontekście celów Strategii Europa 2020. Wartość sfinansowanego księgozbioru to ok. 30 tys. zł.

W tabeli 1 zestawiono, jak w poszczególnych latach kształtowały się ilościowo zbiory zwarte i jaki wpływ na gromadzenie wywarły dotacje pozabudżetowe. Na przykładzie roku akademickiego 2011/2012 w całości pokazano ewidencję zbiorów z ewidencji druków zakcesjonowanych. W zestawieniu, prezentując kolejne lata, wyszczególniono te zbiory, których zakup był finansowany lub dofinansowany ze środków zewnętrznych. W tabeli ujęto również nabytki $\mathrm{z}$ dotacji ministerialnej, o której mowa będzie w dalszej części artykułu.

Na księgozbiór biblioteki składają się:

- audiobooki,

- bazy danych,

— dokumenty elektroniczne (CD-ROM-y),

— księgozbiór podręczny,

— materiały (raporty roczne banków, druki UE, banków i in.),

— podręczniki,

- wydawnictwa ciagge: czasopisma,

- wydawnictwa ciągłe: zeszyty, roczniki naukowe itp.

Zestawienie zawiera wszystkie składowe księgozbioru z wyjątkiem czasopism oraz baz danych. 
Tabela 1. Udział ilościowy i procentowy nabytków finansowanych ze źródeł zewnętrznych

Ewidencja zbiorów zakcesjonowanych za rok akademicki 2011/2012 (1.10.2011-30.09.2012)

\begin{tabular}{|c|c|c|c|c|}
\hline $\begin{array}{l}\text { Oznaczenie księgi } \\
\text { inwentarzowej }\end{array}$ & $\begin{array}{l}\text { Sposób } \\
\text { nabycia }\end{array}$ & $\begin{array}{l}\text { Liczba } \\
\text { wolumi- } \\
\text { nów }\end{array}$ & $\begin{array}{l}\text { Ilościowy i pro- } \\
\text { centowy udział } \\
\text { nabytków z fundu- } \\
\text { szy UE }\end{array}$ & $\begin{array}{l}\text { Ilościowy i procentowy } \\
\text { udział dotacji ministerialnej } \\
\text { dla osób niepełnosprawnych }\end{array}$ \\
\hline \multirow[t]{3}{*}{$\begin{array}{c}\text { Dokumenty ciągłe } \\
\text { (bez czasopism) }\end{array}$} & dar & 29 & & \\
\hline & kupno & 6 & & \\
\hline & wymiana & 45 & & \\
\hline $\begin{array}{l}\text { Dokumenty } \\
\text { elektroniczne }\end{array}$ & dar & 29 & & \\
\hline Materiały & dar & 35 & & \\
\hline \multirow[t]{3}{*}{$\begin{array}{l}\text { Księgozbiór } \\
\text { podręczny }\end{array}$} & dar & 444 & & \\
\hline & kupno & 740 & $740(100 \%)$ & \\
\hline & wymiana & 76 & & \\
\hline \multirow[t]{3}{*}{ Podręczniki } & dar & 244 & & \\
\hline & kupno & 100 & $100(100 \%)$ & \\
\hline & wymiana & 1 & & \\
\hline \multirow[t]{6}{*}{ Depozyt } & depozyt & 14 & & \\
\hline & Razem: & 1473 & & \\
\hline & dar & 781 & & \\
\hline & depozyt & 14 & & \\
\hline & kupno & 846 & $840(98,95 \%)$ & \\
\hline & wymiana & 122 & & \\
\hline
\end{tabular}

Ewidencja zbiorów zakcesjonowanych za rok akademicki 2012/2013 (1.10.2012-30.09.2013)

\begin{tabular}{|c|c|c|c|c|}
\hline $\begin{array}{c}\text { Oznaczenie księgi } \\
\text { inwentarzowej }\end{array}$ & $\begin{array}{c}\text { Sposób } \\
\text { nabycia }\end{array}$ & $\begin{array}{c}\text { Liczba } \\
\text { wolumi- } \\
\text { nów }\end{array}$ & $\begin{array}{c}\text { Ilościowy i pro- } \\
\text { centowy udział } \\
\text { nabytków z fundu- } \\
\text { szy UE }\end{array}$ & $\begin{array}{c}\text { Ilościowy i procentowy } \\
\text { udział dotacji ministerialnej } \\
\text { dla osób niepełnosprawnych }\end{array}$ \\
\hline Audiobooki & kupno & 78 & $11(78,5 \%)$ & $78(100 \%)$ \\
\hline $\begin{array}{c}\text { Dokumenty } \\
\text { elektroniczne }\end{array}$ & kupno & 14 & $1100 \%)$ \\
\hline Materiały & kupno & 25 & & $25(100)$ \\
\hline
\end{tabular}




\begin{tabular}{|c|c|c|c|c|}
\hline $\begin{array}{l}\text { Księgozbiór } \\
\text { podręczny }\end{array}$ & kupno & 958 & $359(52,1 \%)$ & $410(5,9 \%)$ \\
\hline & Razem: & 1598 & & \\
\hline & dar & 535 & & \\
\hline & depozyt & 5 & & \\
\hline & kupno & 1260 & $370(37 \%)$ & $513(40,7 \%)$ \\
\hline & wymiana & 67 & & \\
\hline \multicolumn{5}{|c|}{ Ewidencja zbiorów zakcesjonowanych za rok akademicki 2013/2014 (1.10.2013-30.09.2014) } \\
\hline $\begin{array}{l}\text { Oznaczenie księgi } \\
\text { inwentarzowej }\end{array}$ & $\begin{array}{l}\text { Sposób } \\
\text { nabycia }\end{array}$ & $\begin{array}{l}\text { Liczba } \\
\text { wolumi- } \\
\text { nów }\end{array}$ & $\begin{array}{l}\text { Ilościowy i pro- } \\
\text { centowy udział } \\
\text { nabytków z fundu- } \\
\text { szy UE }\end{array}$ & $\begin{array}{l}\text { Ilościowy i procentowy } \\
\text { udział dotacji ministerialnej } \\
\text { dla osób niepełnosprawnych }\end{array}$ \\
\hline \multirow[t]{2}{*}{$\begin{array}{l}\text { Księgozbiór } \\
\text { podręczny }\end{array}$} & kupno & 1484 & $172(11,5 \%)$ & $1245(83,9 \%)$ \\
\hline & wymiana & 66 & & \\
\hline \multirow[t]{6}{*}{ Podręczniki } & kupno & 68 & $62(91,2 \%)$ & \\
\hline & Razem: & 2269 & & \\
\hline & dar & 588 & & \\
\hline & depozyt & & & \\
\hline & kupno & 1560 & $234(15 \%)$ & $1246(79,9 \%)$ \\
\hline & wymiana & 117 & & \\
\hline \multicolumn{5}{|c|}{ Ewidencja zbiorów zakcesjonowanych za rok akademicki 2014/2015 (1.10.2014-30.09.2015) } \\
\hline $\begin{array}{l}\text { Oznaczenie księgi } \\
\text { inwentarzowej }\end{array}$ & $\begin{array}{l}\text { Sposób } \\
\text { nabycia }\end{array}$ & $\begin{array}{l}\text { Liczba } \\
\text { wolumi- } \\
\text { nów }\end{array}$ & $\begin{array}{l}\text { Ilościowy i pro- } \\
\text { centowy udział } \\
\text { nabytków z fundu- } \\
\text { szy UE }\end{array}$ & $\begin{array}{l}\text { Ilościowy i procentowy } \\
\text { udział dotacji ministerialnej } \\
\text { dla osób niepełnosprawnych }\end{array}$ \\
\hline $\begin{array}{l}\text { Księgozbiór } \\
\text { podręczny }\end{array}$ & kupno & 775 & $80(10,3 \%)$ & $372(48 \%)$ \\
\hline \multirow[t]{4}{*}{ Podręczniki } & kupno & 60 & $35(58 \%)$ & \\
\hline & Razem: & 1392 & & \\
\hline & dar & 481 & & \\
\hline & kupno & 915 & $115(12,6 \%)$ & $372(44 \%)$ \\
\hline
\end{tabular}


Ewidencja zbiorów zakcesjonowanych za rok akademicki 2015/2016 (1.10.2015-1.07.2016)

\begin{tabular}{|c|c|c|c|c|}
\hline $\begin{array}{c}\text { Oznaczenie księgi } \\
\text { inwentarzowej }\end{array}$ & $\begin{array}{c}\text { Sposób } \\
\text { nabycia }\end{array}$ & $\begin{array}{c}\text { Liczba } \\
\text { wolumi- } \\
\text { nów }\end{array}$ & $\begin{array}{c}\text { Ilościowy i pro- } \\
\text { centowy udział } \\
\text { nabytków z fundu- } \\
\text { szy UE }\end{array}$ & $\begin{array}{c}\text { Ilościowy i procentowy } \\
\text { udział dotacji ministerialnej } \\
\text { dla osób niepełnosprawnych }\end{array}$ \\
\hline $\begin{array}{c}\text { Księgozbiór } \\
\text { podręczny }\end{array}$ & kupno & 547 & & $315(57,6 \%)$ \\
\hline & Razem: & 1112 & & \\
\cline { 2 - 5 } & dar & 460 & & \\
\cline { 2 - 5 } & depozyt & 5 & & $315(57 \%)$ \\
\cline { 2 - 5 } & kupno & 551 & & \\
\cline { 2 - 5 } & wymiana & 96 & & \\
\hline
\end{tabular}

Źródło: opracowanie własne na podstawie ksiąg akcesji (2011-2016) biblioteki WSB w Toruniu.

Przy niewątpliwych korzyściach czerpanych przez bibliotekę WSB z finansowania jej zasobów ze źródeł zewnętrznych (wzbogacanie jej o nowe formy zbiorów oraz nowości wydawnicze) można na podstawie przedstawionego zestawienia zauważyć niepokojące zjawisko. Często dotacje unijne czy ministerialne, zamiast być dodatkową formą finansowania, stają się podstawowym źródłem zakupu wydawnictw zwartych. Przykładowo w roku akademickim 2011/2012 stanowiły prawie $100 \%$, a w 2013/2014 ponad $90 \%$. Grozi to zachwianiem harmonijnego wzrostu zasobów bibliotecznych, gdyż działy tematycznie niezwiązane z realizacją programu unijnego przestają być aktualizowane. Przy zawężonym spojrzeniu władz uczelni na gromadzenie zbiorów w bibliotece, szczególnie w czasach trudności finansowych, kiedy należy oszczędzać, ważne jest, aby zapewnić przynajmniej minimalny budżet na równomierną rozbudowę księgozbioru. Zmniejszanie go czy zastępowanie finansowaniem zewnętrznym może doprowadzić do zubożenia pewnych działów, co natychmiast odczują studenci oraz kadra naukowa uczelni.

\section{Dotacja ministerialna - nowe formy zbiorów w bibliotece}

W roku akademickim 2012/2013 w bibliotece WSB w Toruniu rozpoczęto realizację dotacji Ministerstwa Nauki i Szkolnictwa Wyższego na zadania związane ze stwarzaniem studentom i doktorantom, będącym osobami niepełnosprawnymi, warunków do pełnego udziału w procesie kształcenia w Wyższej Szkole Bankowej w Toruniu. Uczelnia otrzymała z budżetu państwa dotację przeznaczoną na 
finansowanie kosztów realizacji inwestycji służących kształceniu niepełnosprawnych studentów i doktorantów ${ }^{12}$.

Zgodnie z zaleceniami Ministerstwa Nauki i Szkolnictwa Wyższego uczelnie samodzielnie podejmują decyzje, na jakie zadania związane z procesem kształcenia studentów i doktorantów niepełnosprawnych przeznaczą tę dotację.

Wśród praktykowanych przez uczelnie zadań znajdują się m.in.:

— zakup sprzętu i urządzeń specjalistycznych wspomagających proces kształcenia (w kwocie jednostkowej nieprzekraczającej 3500 zł),

— zakup literatury specjalistycznej i naukowej,

— opracowywanie materiałów dydaktycznych i naukowych w formie dostępnej osobom z różnego rodzaju niepełnosprawnościami ${ }^{13}$.

W tabeli 2 pokazano, jakiego rodzaju nowe formy znalazły zastosowanie w bibliotece WSB w Toruniu. Tu należy zaznaczyć, że wszystkie urządzenia wypożyczane są studentom niepełnosprawnym, pozostali użytkownicy mogą korzystać z nich na miejscu, w czytelni (z wyjątkiem czytników z wgranymi kolekcjami e-książek, one również są wypożyczane).

Tabela 2. Zestawienie zakupionych materiałów i urządzeń

\begin{tabular}{|l|c|}
\hline \multicolumn{1}{|c|}{ Materiały dydaktyczne } & Liczba \\
\hline e-booki (książki w formacie PDF i e-mobi) & 253 \\
\hline \multicolumn{1}{|c|}{ Urządzenia } & 160 \\
\hline audiobooki & Liczba \\
\hline czytnik e-booków Ereader Vedia K 10, 4 GB 6 cali, papier elektroniczny & 20 \\
\hline discman CD/MO3 Philiphs EXP2546, & 11 \\
\hline słuchawki z mikrofonem Sony MDR570 & 11 \\
\hline tablet Powertab MID08 & 20 \\
\hline
\end{tabular}

Źródło: opracowanie własne.

Biblioteka, realizując dotację ministerialną, zakupiła czytniki, a następnie e-booki, które zostały wgrane na urządzenia i obecnie są z powodzeniem wypożyczane użytkownikom (część czytników została przekazana bibliotece WSB w Bydgoszczy). Z tej samej dotacji zakupiono audiobooki o tematyce społeczno-ekonomicznej oraz dofinansowano zakup e-książek na platformie IBUK Libra

${ }^{12}$ Ministerstwo Nauki i Szkolnictwa Wyższego. Wsparcie niepelnosprawnych studentów i doktorantów, http://www.nauka.gov.pl/wsparcie-niepelnosprawnych-studentow-i-doktorantow/ [dostęp: 10.07.2016].

${ }^{13}$ Ministerstwo Nauki i Szkolnictwa Wyższego. Komunikat dla uczelni niepublicznych w sprawie wykorzystania dotacji podmiotowych, http://www.nauka.gov.pl/szkolnictwo-wyzsze/komunikat-dlauczelni-niepublicznych-w-sprawie-wykorzystania-dotacji-podmiotowych.html [dostęp: 13.06.2017]. 
(dodać należy, iż od roku akademickiego 2013/2014 dotacja ministerialna przeznaczana jest na zakup książek na platformie IBUK oraz zakup literatury specjalistycznej i naukowej. Skalę zakupu zbiorów zwartych tradycyjnych [papierowych] obrazuje tabela 1).

Przy podejmowaniu decyzji o wzbogaceniu biblioteki o nowe formy zbiorów ważny był format, w jakim zostaną zakupione dokumenty, czy będzie to wersja elektroniczna on-line, plik czy CD-ROM, czy będą zakupione na własność, na licencjach i na jakich warunkach (negocjowanie umów w przypadku IBUK Libra).

Przed podjęciem decyzji dotyczących wyboru nośnika gromadzonych materiałów należało rozważyć zagadnienia, takie jak:

- cele i zadania biblioteki (czy i jak przyszłe zbiory będą wpisywały się w politykę gromadzenia),

— dostępność dokumentów w postaci elektronicznej,

— potrzeby i preferencje użytkowników ${ }^{14}$.

Przy czym badając dostępność dokumentów w postaci elektronicznej, analizowano:

1. Tryb dostępu czytelnika do e-książki:

— on-line — bez możliwości pobrania książki elektronicznej na swój komputer (IBUK Libra.pl),

— off-line - tj. dostęp po pobraniu na komputer (tak wyglądał zakup e-booków wgrywanych na czytniki, zakupione pliki wgrywano na komputer „matkę”, a stamtąd kopiowano dozwoloną ilość na czytniki) ${ }^{15}$.

2. Format zapisu e-publikacji:

- HTML — sekwencja plików grupujących strony, rozdziały itp., przechowywanych na serwerze www albo generowanych dynamicznie z bazy zawierającej książki elektroniczne ${ }^{16}$,

— PDF i DJV — w postaci pliku lub sekwencji plików, a także wiążącego te pliki skorowidza oraz formaty dedykowane czytnikom (e-mobi, e-pub, pdf).

3. Formę ochrony praw autorskich:

- użytkownik posiada hasło, zakres uprawnionych IP — obecnie w bibliotekach WSB zastąpione przez licencję kampusową na serwer proxy HAN (ang. Hidden Automatic Navigator) — w przypadku bibliotek WSB dostęp do IBUK Libra i monografii w prenumerowanych bazach danych,

${ }^{14}$ A. Sadoch, Elektroniczne materiaty biblioteczne w procesie ksztaltowania zasobów Biblioteki Sejmowej, „EBIB Materiały Konferencyjne” 2005, nr 11, http://www.ebib.pl/publikacje/ matkonf/grom2/sadoch.php [dostęp: 10.07.2016].

15 I. Statkiewicz, Analiza wykorzystania ksiażek elektronicznych, „EBIB Materiały Konferencyjne" 2005, nr 11, http://www.ebib.pl/publikacje/matkonf/grom2/statkiewicz.php [dostęp: 10.07.2016].

${ }^{16}$ Ibidem. 
— szyfrowane treści DRM — zarządzanie prawami cyfrowymi (ang. digital rights management) to system zabezpieczeń oparty na mechanizmach kryptograficznych lub innych metodach ukrywania treści, którego celem jest przeciwdziałanie używaniu danych $\mathrm{w}$ formacie elektronicznym w sposób sprzeczny $\mathrm{z}$ wolą ich wydawcy (w przypadku bibliotek WSB w ten sposób są szyfrowane e-książki na czytnikach),

— Watermark, inaczej zwany „markerem” lub „znakiem wodnym” — stanowi metodę zabezpieczenia udostępnianego w Internecie tzw. contentu, czyli wszelkich treści cyfrowych (muzyka, film, audiobook). Watermark to unikalne „oznaczenie”, niepowtarzalny identyfikator kopii pliku, wprowadzony na całej długości trwania pobranego pliku (w zbiorach bibliotek WSB stosowany w audiobookach) ${ }^{17}$.

Decyzja o zakupie nowych form książek była podyktowana potrzebami osób niepełnosprawnych studiujących na uczelni, jak również dążeniem uczelni WSB do bycia e-uczelnią. W celu ułatwienia studentom nauki, zapewnienia stałego, szybkiego i łatwego kontaktu z działami obsługowymi oraz dostępu do ważnych informacji WSB wprowadziło zintegrowany system wirtualnej obsługi studenta, w którego pakiet wchodzi e-indeks, czyli wirtualny formularz ocen i Extranet specjalna platforma on-line, dzięki której uczelnia jest do dyspozycji studentów 24 godziny na dobę. W tę politykę muszą wpisywać się zasoby biblioteczne — tak też się stało m.in. dzięki realizacji dotacji ministerialnej.

\section{Zakończenie}

W artykule przedstawiono studium przypadku na przykładzie biblioteki Wyższej Szkoły Bankowej w Toruniu. Ta niewielka placówka uczelni niepublicznej zatrudniająca na pełne etaty 4 pracowników (3 kustoszy i jednego starszego bibliotekarza) oraz personel pomocniczy (2-3 pracowników zatrudnionych na umowę zlecenie) podejmuje za pomocą środków pozabużetowych działania otwierające ją na nowe formy zbiorów. Stara się w miarę swoich możliwości wykorzystywać elementy Total Quality Management (TQM) w uzyskaniu trzech podstawowych celów: satysfakcji użytkowników biblioteki, podnoszenia jakości i ciągłego doskonalenia pracy biblioteki, zaangażowania pracowników biblioteki i ich satysfakcji z wykonywanej pracy. Coraz większe zapotrzebowanie na wiedzę, ciągły rozwój rynku wydawniczego, jak zauważa Janina Przybysz w publikacji Strategia gromadzenia zbiorów w małej bibliotece naukowej, powoduje zwrócenie się ku wielomedialności ${ }^{18}$. Stąd współistnienie w bibliotece naukowej publikacji

\section{${ }^{17}$ Ibidem.}

18 J. Przybysz, Strategia gromadzenia zbiorów w małej bibliotece naukowej (na przykładzie biblioteki Wyższej szkoły Bankowej w Poznaniu), [w:] Strategie gromadzenia zbiorów w bibliotekach polskich, Materiały z IV Ogólnopolskiej Konferencji Naukowej Pobierowo, 15-17 września 2011, red. U. Ganakowska, M. Różycka, Szczecin 2012, s. 115-116. 
elektronicznych z wydawanymi tradycyjnie w przypadku toruńskiej biblioteki funkcjonuje dzięki dofinansowaniu unijnemu oraz ministerialnemu. Nie zmienia to faktu, iż dla harmonijnego rozwoju biblioteki konieczny jest określony, stały budżet wewnętrzny, dzięki któremu biblioteka może wypełniać swoje zadania. Drastyczne zmniejszanie budżetu i zastępowanie go finansowaniem zewnętrznym może doprowadzić do skreślenia niektórych usług lub zaburzyć zrównoważony rozwój zbiorów.

\section{Bibliografia}

Chachlikowska A. et al., Badania wykorzystania przez polskie biblioteki naukowe środków europejskich, grantów ministerialnych i samorzadowych oraz dotacji sponsorów w latach 2000-2008, „Biblioteka” 2009, nr 13 (22), http://repozytorium.amu.edu.pl/jspui/bitstream/10593/637/108.pdf [dostęp: 10.07.2016].

Matynia T., Podstawy prawne tworzenia i funkcjonowania niepublicznych szkót wyższych w świetle ustawodawstwa polskiego w latach 1920-2013, „Homines Hominibus” 2012, nr 8, s. 77-98.

Ministerstwo Nauki i Szkolnictwa Wyższego. Komunikat dla uczelni niepublicznych w sprawie wykorzystania dotacji podmiotowych, http://www.nauka.gov.pl/szkolnictwo-wyzsze/komunikat-dla-uczelni-niepublicznych-w-sprawie-wykorzystania-dotacji-podmiotowych.html [dostęp: 13.06.2017].

Ministerstwo Nauki i Szkolnictwa Wyższego. Wsparcie niepelnosprawnych studentów i doktorantów, http://www.nauka.gov.pl/wsparcie-niepelnosprawnych-studentow-i-doktorantow/ [dostęp: 10.07.2016].

Ministerstwo Nauki i Szkolnictwa Wyższego. Zadania Ministerstwa w dziedzinie szkolnictwa wyższego, http://www.nauka.gov.pl/szkolnictwo-wyzsze/ [dostęp: 10.02.2017].

Przybysz J., Strategia gromadzenia zbiorów w małej bibliotece naukowej (na przyktadzie biblioteki Wyższej Szkoły Bankowej w Poznaniu), [w:] Strategie gromadzenia zbiorów w bibliotekach polskich, Materiały z IV Ogólnopolskiej Konferencji Naukowej Pobierowo, 15-17 września 2011, red. U. Ganakowska, M. Różycka, Szczecin 2012, s. 111-123.

Regulamin Systemu Biblioteczno-Informacyjnego Wyższej Szkoły Bankowej w Gdańsku, http:// www.wsb.pl/gdansk/sites/wsb.pl.gdansk/files/default_images/biblioteka/regulamin_biblioteki_2013.pdf [dostęp: 20.06.2016].

Regulamin Systemu Biblioteczno-Informacyjnego Wyższej Szkoty Bankowej w Poznaniu, http:// www.wsb.pl/poznan/sites/wsb.pl.poznan/files/regulamin_systemu_bib_inf.pdf [dostęp: 20.06.2016].

Regulamin Systemu Biblioteczno-Informacyjnego Wyższej Szkoły Bankowej w Toruniu, http://www. wsb.pl/torun/sites/wsb.pl.torun/files/biblioteka/regulamin_2015.pdf7 [dostęp: 20.06.2016].

Regulamin Systemu Biblioteczno-Informacyjnego Wyższej Szkoły Bankowej we Wrocławiu, http:// www.wsb.pl/wroclaw/sites/wsb.pl.wroclaw/files/reg_biblio_wsb-ww_2013.pdf [dostęp: 20.06.2016].

Sadoch A., Elektroniczne materiały biblioteczne w procesie ksztaltowania zasobów Biblioteki Sejmowej, „EBIB Materiały Konferencyjne” 2005, nr 11, http://www.ebib.pl/publikacje/matkonf/ grom2/sadoch.php [dostęp: 10.07.2016].

Statkiewicz I., Analiza wykorzystania ksiażek elektronicznych, „EBIB Materiały Konferencyjne" 2005, nr 11, http://www.ebib.pl/publikacje/matkonf/grom2/statkiewicz.php [dostęp: 10.07.2016]. 
Szkoły wyższe i ich finanse w 2014 r. Gtówny Urząd Statystyczny, http://stat.gov.pl/obszary-tematyczne/edukacja/edukacja/szkoly-wyzsze-i-ich-finanse-w-2014-r-,2,11.html [dostęp: 10.07.2016].

Uczelnie niepubliczne i zwiazki uczelni niepublicznych. POL-on, https://polon.nauka.gov.pl/opi/aa/ rejestry/run?execution=e3s1 [dostęp: 20.06.2016].

Urban B., Finanse bibliotek niepaństwowych szkót wyższych — zarys tematyki, „Biuletyn EBIB” 2009, nr 8 (108), http://www.ebib.pl/2009/108/a.php?urban [dostęp: 20.06.2016].

Wiki PSRP. Dotacja Ministerstwa Nauki i Szkolnictwa Wyższego na zadania zwiąane ze stwarzaniem studentom i doktorantom, będącym osobami niepetnosprawnymi, warunków do petnego udziatu w procesie kształcenia, http://wiki.psrp.org.pl/Dotacja_Ministerstwa_Nauki_i_Szkolnictwa_Wy\%C5\%BCszego_na_zadania_zwi\%C4\%85zane_ze_stwarzaniem_studentom_i_doktorantom,_b\%, $4 \% 99 \mathrm{~d} \% \mathrm{C} 4 \% 85 \mathrm{cym}$ osobami_niepe $\% \mathrm{C} 5 \% 82$ nosprawnymi,_warunk $\% \mathrm{C} 3 \% \mathrm{~B} 3 \mathrm{w}$ _do_pe $\% \mathrm{C} 5 \% 82$ nego_udzia $\% \mathrm{C} 5 \% 82 \mathrm{u}$ _w_procesie_kszta $\% \mathrm{C} 5 \% 82$ cenia [dostęp: 20.06.2016].

\title{
The impact of ministerial grants and EU funds on the library of a non-public higher education institution (as seen in the Library of the WSB University of Toruń)
}

\begin{abstract}
Summary
The article presents an outline of the legal basis of the operation of non-public higher education institutions and their place in the Polish education system. This is the background for the author's analysis of the library and information systems of business schools that are part of the TEB SA group. The author focuses on extrabudgetary forms of expanding the library of a non-public university through the use of ministerial and EU grants. The case study presented in the article is that of the Library of the WSB University of Torun. The author examines, on the basis of books inventoried in 2011-2016, the volume and percentage share of books acquired thanks to EU funds and ministerial grants. She demonstrates how the Library - which, owing to the business nature of the University, has specialist collections at its disposal - acquires new forms of books (e-books in mobi and pdf files, e-book readers, audiobooks etc.) as well as educational aids. She presents examples of how extrabudgetary funds can support and complement the main budget of the library of a non-public university in its initiatives aimed at creating a modern facility.
\end{abstract}

KEYWORDS: private university libraries, EU grants in the library, ministerial grants, library management. 